Physics International 1 (1): 9-15, 2010

ISSN 1948-9803

(C) 2010 Science Publications

\title{
Distribution and Determining of Urban Sprawl in Kerman with Emphasis on Kariz Water System
}

\author{
${ }^{1}$ Ali Hosseini, ${ }^{1}$ Mohammad Shabanifard, \\ ${ }^{2}$ Mostafa Rashidi and ${ }^{3}$ Mamohammad Reza Saiydzade \\ ${ }^{1}$ Department of Geography and Urban Planning, University of Tehran, \\ Alley Azin, Qouds Str, Enghelab Ave, Tehran, Iran \\ ${ }^{2}$ Department of Geography and Political Geography, University of Tehran, Iran \\ ${ }^{3}$ Department of Political Geography, Azad University, North Tehran, Iran
}

\begin{abstract}
Problem statement: Urban sprawl is one of the contemporary issues of cities all over the world. The Kariz system consists of underground channels that convey water from aquifers in highlands to the surface at lower levels by gravity. The problem of water shortage in arid and semi-arid regions is one of low rainfall and uneven distribution throughout the season, which makes rain fed agriculture a risky enterprise. The system supplies $75 \%$ of all the water used in that country, providing water not only for irrigation but also for house-hold consumption. Approach: This study explained and determined role Karizs in urban sprawl in Kerman. Results: Absence of planning for maintaining the Kariz s within the urban planning and their extinction have led to inclination toward other methods such as digging few deep wells during forth recent decades. Conclusion: A Kariz system has a profound influence on the lives of the water users. It allows those living in a desert environment adjacent to a mountain watershed to create a large oasis in an otherwise stark environment.
\end{abstract}

Key words: Urban water systems, urban sprawl, Kariz (Qanat), arid areas, Kerman

\section{INTRODUCTION}

The traditional systems of water management within different clusters of urban plan have shown to be effective in continuously providing for the people's needs while enhancing effective maintenance. This system was replaced by the conventional piped system when the population outgrew their clusters during the colonial times (Twahir, 1976). This could have been due to the existing cultural diversity of migrants or just for the need to control crucial resources. With the decline in economy and social structure of the town, there has been a shortage of resources, expertise and incentive to maintain and manage the water supply system for the continuing and growing use of the community (Barshan, 2008). The postcolonial era has been depicted by un-maintained water system causing frequent water loss, health risks and damage to historic buildings. It then becomes necessary to revert and compliment the current water system with the traditional forms of administration in a bid to aim at enhancing community participation and consequently efficient management of water supplies.

The options analyzed towards achieving this are by decentralization strategies, people empowerment and private sector incorporation as strategies of subsidizing and improving the existing administrative system (Rahimi and Momeni, 2004).

Policymaking involves the following actors like policy makers, infrastructure managers who service policy and technology, operational staff for daily provision and the users. These actors vary from National, regional and local governments to private firms, NGOs and donors. Problems faced by the water supply systems affect economic performance, congestions, environmental degradation and poor health conditions. Hence improvement of efficient maintenance is through:

- Meeting specific user demands

- Maintenance programmes that provide incentives finance and encourage self-help

- Devolution of responsibilities to local governments

- Systems maintenance to reduce life cycle costs

- Equity in fee systems having special programmes for those incapable of paying

Demand orientation responds to the consumer services, technology and pricing. There is a need to

Corresponding Author: Ali Hosseini, Department of Geography, University of Tehran, Alley Azin, Qouds Str, Enghelab Ave, Tehran, Iran 
derive consistency between demands required and provision whereby the issues of priority in question are accessibility, capacity of service, diversity offered, reliable quality, flow time and price. There is a need to identify present and future demands in order to focus on improving systems with greatest shortcomings; financial, management and technical.

Sprawl is a pattern and pace of land development in which the rate of land consumed for urban purposes exceeds the rate of population growth and which results in an inefficient and consumptive use of land and its associated resources (Soule, 2006; Burchell et al., 2005). Bear in mind that how sprawl is defined depends upon the perspective of who presents the definition (Foster-Bey, 2002). For example, disease analogies such as cancerous growth and virus have been used to describe sprawl. The Sierra Club describes suburban sprawl as irresponsible, often poorly-planned development that destroys green space, increases traffic and air pollution, crowds schools and drives up taxes. Tamer descriptions of sprawl include low-density urbanization and discontinuous development. Sprawl must be considered in a space-time context (Haase and Nuiss1, 2007). It is not simply the increase of urban lands in a given area, but the rate of its increase relative to population growth (Ewing, 1997). Sprawl occurs when the rate of land conversion and consumption for urban uses exceeds the rate of population growth for a given area over a specified period of time (Syful Islam, 2007). The Chesapeake Bay and Mid-Atlantic from Space project uses impervious surfaces as an indicator of urbanization within this region. The growth of impervious lands between 1990 and 2000 is used to assess urban development and the spread of sprawl (Frumkin et al., 2004).

Water is one of the main primary human needs and is among the basic criteria of environmental probability. These days, water shortage is proposed as an important crisis in the world. Regarding to the increasing growth of the worlds population, especially in developing countries and uncontrolled cultivation and high rate of water consumption, the crisis is treating a majority of human societies particularly in developing world.

Probably, excavating and constructing the Karizs has been the best method to battle with water shortage in some arid regions similar to Iran (Kardavani, 2005). This water system according to many researchers and Kariz professionals has been invented in Iran for the first time and it has provided a large volume of farming and drinking water of so many cities and villages from few last decades onwards (Stiros, 2006). Nevertheless, rapid growth of Iranian urbanization whether in the form of population growth and number in cities or overspill and explosive growth of urban areas, which can be named "urban sprawl", has ended in extinction of this sustainable water supply (Abbaszadeh, 2005).

Kerman city is located in an almost arid or semiarid region in south part of Iran, a large number of Karizs have been existed there (Zendeh Del, 1999). These Karizs are made to be used for farming consumption and urban drinking water consumption, which approximately all of them have been destroyed because of over increased growth and development. It should be mentioned that not only the city could not consume this safe, cheap and sanitary source- which is compatible with environment and sustainable development, but also have voluntary and involuntary destroyed the source and has converted the utilized Karizs to unutiliz ones (Schneier-Madanes and MarieFrancoise, 2010; McLaren et al., 1991). Therefore, based on the present circumstances, the Karizs are not able to be a source of water supply, but rather have altered to some reservoirs for attracting sewage and a dangerous body incompatible with the safe environment.

Kariz on traditional water systems in Iran: Kariz (Qanat) is an ancient water provision technology that can be described as the greatest contribution made by Iranians to hydraulics. This system must have been started at least 5000 years ago in Iran. Kariz system is usually found in central Iran toward the east and southeast of Iran (Municipality of Kerman, 2005).

Some existing ancient example of water provision in Iran are: old Zavareh Kariz dating back to 5000 years ago, $350 \mathrm{~m}$ depth master well of Gonabad Kariz dating back to 2500 years ago, $40 \mathrm{~km}$ long a aqueduct of Chogha Zanbil water refinery installation dating at least back to 3250 years ago and the 1000 year-old water distribution network of Milan village in East Azerbaijan province (Power Ministry, 2005).

Therefore, since antiquity supplying and restoring water for drinking, irrigating, washing, etc have been the essential issue for survival.

That is why all those Kariz systems, water reservoirs, icehouses, water mills, water dams, bridges and diversion dams have been built (Kuros and Khaneiki, 2007; Sameny, 1993).

Kariz is a mining installation or technique using galleries or canals to extract water from the depths of the earth to the ground. In fact, water is brought by gravity flow from the upper end, where it seeps into the gallery to a ground surface outlet and irrigation canal at its lower end. This is done by means of a gently sloping tunnel.

Kariz mining technique: The first step in making a Kariz is to sink a trial shaft (gamaneh) to prove the 
presence and determine the depth of the water table. When the trial shaft is sunk and water is reached, it must be determined if the well has struck a constant flow of water in an impermeable stratum. If so the alignment and slope of the Kariz from the shaft has to be established. This shaft becomes the mother well (Kardavani, 2009).

The gradient of the gallery must not be too steep, because the water, then, will flow too fast and erode the walls and the tunnel will fall in Working on Kariz making usually begins at the lower end where its water is to come to the surface. By spike and shovel, the tunnel starts to be dug back toward the mother well. At times it begins simultaneously at both ends.

Vertical shafts are sunk from the surface to the tunnel approximately every $25-40 \mathrm{~m}$, or are sunk first and then connected by a tunnel. Mud or stone linings at their upper parts strengthen these shafts (Fig. 1 and 2).

The soil excavated is moved to the surface in a bucket by a windlass. If the shaft is too deep a second windlass may be set halfway down in a niche. Usually there accumulates a ring of soil around the shaft on the surface. So, looking from the air, sets of wells look like a line of small craters (Semsar Yazdi et al., 2005).

The gradient of a Kariz is established by the use of a spirit level suspended between two pieces of cord, each about 9 meters long. In a short Kariz, the gradient varies from 1:1000 to 1: 1500, but in a long one, it is nearly horizontal.

In some cases, when Kariz route slope needed to be steeper, they usually broke the route line at one point and let water to another level lower than the original level. Therefore, an underground waterfall was created.

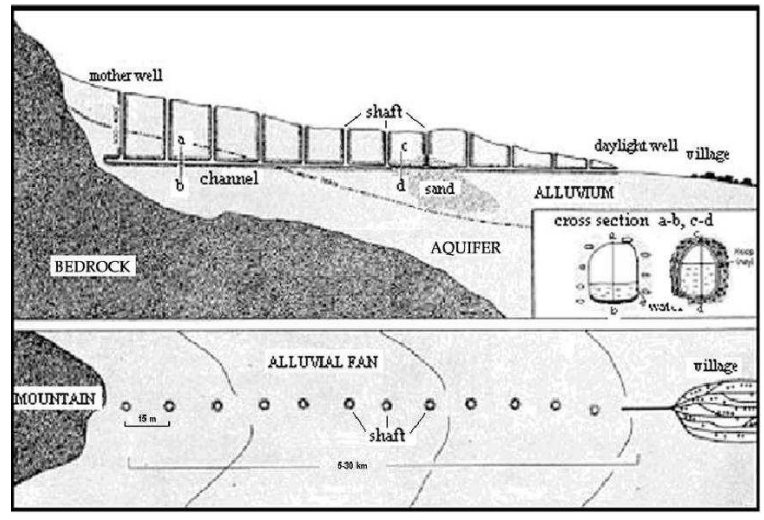

Fig. 1:Profile of a Kariz: Cross section and Aerial view of a Kariz. Karizs are ancient water supply systems constructed using a simple technology. The vertical shafts are not "wells," despite the term "chain-of-wells" often used to describe their appearance on the landscape
Knowing about the water energy at such points, people built water mills to make use of the water energy for other purposes like grinding cereals.

The discharge of the water of Kariz varies according to ground water characteristics, the nature of the soil and season. Those that tap a permanent aquifer usually have a constant flow throughout the year. If a Kariz does not tap a stable groundwater source or is in porous soil, its flow may be reduced to virtually nothing in summer, or in a dry year (Barshan, 2010). The flow of some Kariz may reach $1750 \mathrm{~L}$ a minute, but that of the majority of Kariz systems are much smaller, dropping to approximately $15 \mathrm{~L}$ a minute (Agricultural Committee of Jihad Sazandegi of Kerman, 2009).

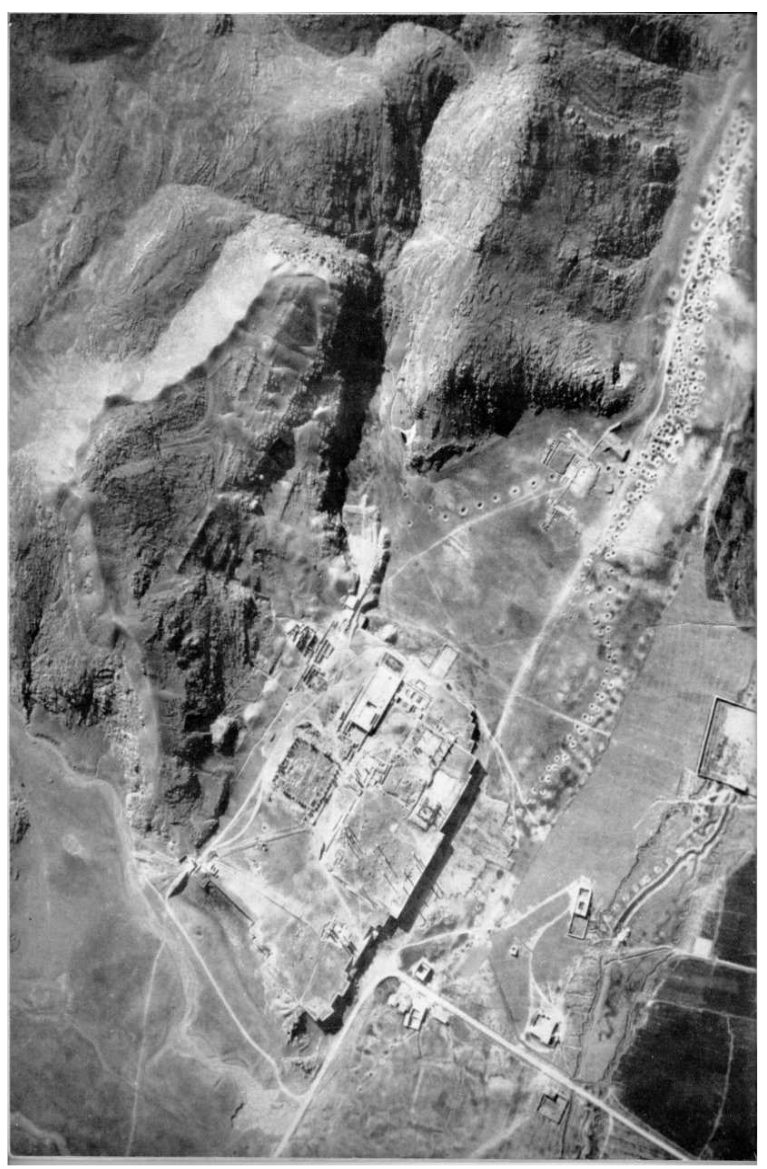

Fig. 2: Satellite image form Kariz in Kerman: Karizs Converging on the City of Kirman. Built during the course of many centuries, large numbers of Karizs converge on most Iranian Plateau cities. Some of these old Kariz tunnels cross back and forth between channels, others are twin Karizs one or both of which may be active and many have been abandoned 
Ownership and distribution of water in Kariz systems: Frequently the ownership of the land where Kariz is made in is in different hands and the water is bought and sold. Some landlords endow the Kariz routes in their lands partially or totally to the whole community living within it (Schneier-Madanes and Marie-Francoise, 2010).

The distribution of the water of a Kariz route is based on time as determined by the users through their representatives (Dehghani, 2009). If the flow of a Kariz is considerably high and the users of the water are numerous, the distribution of the water has to be under a trustworthy official known as mirab who is chosen by the joint users or the government and is paid a certain salary.

A comparative sprawl case study with emphasis on Kariz: In the province of Kerman, that is the largest province of Iran in the year 1990 there was a network of 7388 Karizs with an annual debit of 2.5 billion $\mathrm{m}^{3}$ and an output of $77.8 \mathrm{~m}^{3} \mathrm{sec}^{-1}$. In the same year a few large dams were taken advantage (Barshan, 2010). The Nesah Dam has an elevation of $67 \mathrm{~m}$ from its foundation and has been engineered to provide 31 million $\mathrm{m}^{3}$ per annum, according to which the amount of water to be secured is $1 \mathrm{~m}^{3} \mathrm{sec}^{-1}$. If the water output of Karizs of the province of Kerman was to be compared to the water output of the said dam, it can be noticed that in the year 1990 Karizs of the Kerman province secured 77.8 times more water than the Nesah Dam (Power Ministry, 2007). Three years later, according to official statistics issued by relative authorities, the water output of the same Karizs showed a reduction.

The decline revealed that water output was equivalent to 15 times less the amount of water of the Nesah Dam. So in the sameyear, if $x$ billion was spent as investment for the construction of the dam, instead $15 \mathrm{x}$ billion was lost in financing such projects (Gholoabzadeh, 2002; Kardavani, 2009; Zangiabadi, 2009).

In Kerman city too, Karizs have been one of the most important sources of water supply until several last decades. However, the fast urbanization of last decades in this city, specially its sprawl has caused this sustainable and safe water reservoir to go out from water cycle and to be wholly destroyed because of paying no attention to the Karizs limit (Zangiabadi, 2009). Overspill and unplanned constructions of Kerman because of lack of consideration to the Karizs limit has led to the overextension to their limit and then has caused them to be derelict. In other words, due to overspill sprawl and lack of regard to a large number of existing natural and manmade phenomena over and beneath the city surface, many troubles have arisen. These troubles sometimes lead to heavy financial and spiritual losses. From the manmade phenomena beneath the Kerman city surface are its Karizs, which without any practitioner are existed beneath the city's surface in the form of utilized or unutilized Karizs. These last ones provide the city's drinking water (Gholoabzadeh, 2002). If we do not regulate a systematic planning for management and use of other remained Karizs in Kerman periphery, they also will be demolished because of the city's growth.

\section{MATERIALS AND METHODS}

The following methods have been used to address the above mentioned research questions:

- Literature review on the history of administration of the coastal towns

- Analysis of theoretical literature about the provision of the public good, the role of the private and public sector, strategies of infrastructure management and ways of evaluation of stakeholders involvement.

- Analyze aerial photos, maps and demographic documentation

- Direct onsite observations of the efficiency of the water system, the cultural association on the people and the potential of community empowerment

- Interviews with key-persons and residents on system administration in the past, the current stakeholders, their targets and their extent of involvement in the overall scenario of service provision

- Photographic documentation of water systems sources and Kariz and process urban sprawl Kerman whit satellite image. We used of EASI/PACE Ver. 8.2, ERDAS Ver. 8.4 and ENVI Ver. 3.1 as Satellite Images Processing Software's

- Georeferenced and digited to the scale of 1:50,000 and using the IDRISI Ver.3.2, Arc View Ver. 3.2a and Arc GIS Ver.9.3 as Geographical Information System Software's

\section{RESULTS AND DISCUSSION}

There is no unanimity regarding the longest Kariz in kerman. For instance, Hashu-eieh located in Baghein (31 km long with $22 \mathrm{~L}$ discharge) is the longest Kariz according to the authorities of the regional water organization. Mr. Safi-Nejad believes that the kerman Kariz which is $40 \mathrm{~km}$ long with the depth of $120 \mathrm{~m}$ of 
the mother well and $20 \mathrm{~L}$ discharge per second is considerable. Mr. Petroshevski has recorded the Mahan Kariz $50 \mathrm{~km}$ and Dr. Bastani-Parizi believes that there is a Kariz in kerman which is about $42 \mathrm{~km}$ long with a mother-well enjoying $145 \mathrm{~m}$ of depth. The most splendid Kariz of the province is called pa-ye-kam on the outskirts of Bam with a length of $4600 \mathrm{~m} 4000$ of which is the wet zone. The mother well is 47 meters deep. In Bam and Narmashir, Rashidi Kariz in Barvat and Fazl-Abbad dates back to Rashid-Al-Din Fazlolah's Children and Gardun Kariz precedes Mongols. Chupar is another Kariz dating back to Annahita (Boustani, 2008).

The most improper impact of sprawl on the Karizs is paying no attention to their limit while construction, which leads to extinction of the Karizs and taking them out of the water supply cycle. Sprawl besides that caused Karizs to be unutilized, has provided some secondary outcomes including:

- In a relatively simple example from Mahan near Kirman, water from one of the towns' four Karizs is divided into fifteen sahms with a volume of forty qasabs per day on a twelve day rotation. In this case, each sahm is equal to ninety-six minutes of water once every twelve days or enough water to irrigate forty qasabs of land. In addition, each sahm is subdivided into six dangs, each composed of six habbeh. According to this measurement system, one dang would equal sixteen minutes of water and one habbeh a single minute of water once every twelve days

- Converting the Karizs' route to a sewer for urban sewages: Because Kerman city has no any sewage collector system, in most cases the Kariz acts as the factor of surplus water and sewage conveyer, which this action led to contamination of underground waters

- Possible risks of the Karizs' fall or subsidence: Lack of information of the city's planners, practitioners and citizens about the routes the Karizs run beneath the city has led to paying no attention to these routes while construction. Therefore, this problem due to some various factors like car transition, earthquake, heavy rains and heavy weight of building materials has resulted in the Karizs' slide and subsidence. One of the most important parts of the Kariz is the wells' shaft. There is in the route of the Kariz a well's shaft in every $36 \mathrm{~m}$ in average. Lack of information about their location has led to many financial and spiritual problems. Therefore Kariz routes need to be regularly cleaned and maintained: They are subject to damage and destruction by flash floods. To prevent shafts from being filled with sand, they are covered by stone slabs or other objects

- The problem of Kerman water shortage: Up to water shaft canalization in Kerman city, its Karizs have been the major reservoir for water supply. In addition, these Karizs were used for providing water for the city's gardens, natural woodlands and the fields around. However, by the city's development and land use change, all the Karizs were abandoned and never did play a role to provide the city's drinking or farming water. Of course, just four remained Karizs of Kerman provide the city's drinking water

The comparison between the Kariz and the new methods of water supply; refer to some utilities for the Kariz, including:

- Understanding of subterranean: Although the construction methods are simple, the construction of a Kariz requires a detailed understanding of subterranean geology and a degree of engineering sophistication. The gradient of the Kariz must be carefully controlled too shallow a gradient yields no flow too steep a gradient will result in excessive erosion, collapsing the Kariz. And misreading the soil conditions leads to collapses which at best require extensive rework and at worst, can be fatal for the crew

- The Karizs sustainability: Karizs have been an ancient, sustainable system facilitating the harvesting of water for centuries in Kerman. Advantages of the Kariz system include its simple structure, its harmony with the environment and its ability to tap groundwater in arid areas. It has drawbacks, however, including water loss during seasons of low demand and maintenance costs. Action is necessary to save and preserve these precious assets. Steps toward preserving the ancient system include flood control, organizing groundwater utilization

- To cooling in desert climate: Karizs used in conjunction with a wind tower can provide cooling as well as a water supply. A wind tower is a chimney like structure positioned above the house to catch the prevailing wind. The tower catches the wind, driving a hot, dry breeze into the house; the flow of the incoming air is then directed across the vertical shaft from the Kariz

- To drive underground water mills: In cases where the gradient is steeper, underground waterfalls may be constructed with appropriate design features 
(usually linings) to absorb the energy with minimal erosion. In some cases the water power has been harnessed to drive underground mills

- Karizs are now in decline due to socioeconomic forces and changing technology

- Independence of the Karizs from electric energy or oil materials and mechanical segments of pumping motor and exploiting the underground waters by the gravity force

- Sprawl may contribute to both microbial and chemical contamination of water. On the microbial side, several related phenomena are important. First, stormwater runoff includes large loads of waste from pets and wildlife and nutrients from such sources as fertilizers and streams and rivers downstream from developed areas typically have higher bacterial counts after rainfall

- Sprawl may also contribute to microbial contamination of water through an indirect route

- Sprawl also contributes to chemical contamination of waterways

- The underground waters should not be damaged because of continues exploitation: The Kariz makes equilibrium the layers of water reservoirs and sustains the supply of water reservoirs during the most all-embracing droughts

- More accordance with the local conditions and the sustainable development: The best method of the water supply in the arid and semi-arid regions is constructing the Kariz. Because the Kariz draw the underground water bodies gradually to the ground level, thus is steady and when dryness conditions are dominant, it does not dry soon and has more security. However, other supplementary methods of water supply besides descending the underground water bodies have led to subsidence of Kerman city too

\section{CONCLUSION}

Groundwater management, particularly in arid regions, should be viewed holistically and linked to the sustainable management of the ecosystem. Only through consideration of the interaction between the groundwater and other environmental components can it be possible to elaborate a long-term program for rational groundwater use and protection. Ancient methods of groundwater management, such as the Karizs system, provide an excellent demonstration of human ingenuity to cope with water scarcity.

A Kariz is a water management system used to provide a reliable supply of water to human settlements or for irrigation in hot, arid and semiarid climates and allow the population to live in desert area (Boustani, 2008). A Kariz system has a thoughtful effect on the lives of the water users. It allows whom lives in a desert environment adjacent to a mountain watershed to create a large oasis in an otherwise stark environment. The United Nations and other organizations are encouraging the renewal of traditional water harvesting and supply technologies in arid areas because they feel it is significant for sustainable water utilization. There is no doubt that a large number of kerman Karizs which are invaluable hydraulic structures are disappearing annually, which in turn brings about thea migration of the villagers whose lives are completely dependent upon this system for irrigation. Definitely, the more effort the government makes to spend in Kariz protection and the more supportive the people are, this efficient traditional technology which works in perfect harmony with nature, will remain graceful for years without any need for fuel energy or electricity.

\section{REFERENCES}

Abbaszadeh, G., 2005. Modeling the physical development of the urban texture a long sustainable development, case pattern: Kerman city. Ferdowsi university of Kerman.

Agricultural Committee of Jihad Sazandegi of Kerman, 2009. Reclaiming and reconstructing Qanat. Agricultural Committee of Jihad Sazandegi of Kerman.

Barshan, M., 2008. History of Water in Province Kerman. 1st Edn., Publication of Kerman Center, Kerman, ISBN: 964-9908-51-9, pp: 285.

Barshan, M., 2010. Vision Architects. 1st Edn., Publication Krmanshenasy Center, Kerman, ISBN: 978-964-9908-73-1, pp: 72.

Boustani, F., 2008. Sustainable water utilization in arid region of Iran by Qanats. World Acad. Sci. Eng. Technol., $\quad$ 43: 213-216. http://www.waset.org/journals/waset/v43/v43-40.pdf

Burchell, R., A. Downs, S. Mukherji and B. McCann, 2005. Sprawl Costs: Economic Impacts of Unchecked Development. 1st Edn., Island Press, Washington, Covelo and London, ISBN: 10: 1559635703, pp: 224.

Dehghani, A.R., 2009. Water in the Plateau. 1st Edn., Publication Yazda, Tehran, ISBN: 978-600-554902-7, pp: 86.

Ewing, R., 1997. Is Los Angeles-style sprawl desirable? J. Am. Plan. Assoc., 63: 107-126. DOI: $10.1080 / 01944369708975728$

Foster-Bey, J., 2002. Sprawl, smart growth and economic opportunity. Urban Institute. http://www.urban.org/publications/410536.html 
Frumkin, H., L. Frank and R.J. Jackson, 2004. Urban Sprawl and Public Health: Designing, Planning and Building for Healthy Communities. 1st Edn., Island Press, London, ISBN: 10: 1559633050, pp: 364.

Gholoabzadeh, S.M.A., 2002. Kerman through the History. 1st Edn., Publication of Kerman Center, Kerman, ISBN: 964-6487-49-1, pp: 77.

Haase, D. and H. Nuissl, 2007. Does urban sprawl drive changes in the water balance and policy? Landscape Urban Plann., 1: 1-13. DOI: 10.1016/j.landurbplan.2006.03.011

Kardavani, P., 2005. The Problems of Waters in Iran. 1st Edn., Publication of Kerman Center, Kerman, ISBN: 964-0349-70-4, pp: 250.

Kardavani, P., 2009. Natural Ecosystems Aqua Ecosystems. 1st Edn., University of Tehran Press, Tehran, ISBN: 978-064-0359-58-7, pp: 242.

Kuros, G.R. and R.L. Khaneiki, 2007. Water and Irrigation Techniques in Ancient Iran. 1st Edn., Iranian National Committee on Irrigation and Drainage, Tehran, ISBN: 964-6668-64-X, pp: 52.

McLaren, D., M. Hillman and T. Elkin, 1991. Reviving the City: Towards Sustainable Urban Development. 1st Edn., Continuum International Publishing, London, ISBN: 13: 9780905966830 , pp: 304.

Municipality of Kerman, 2005. Statistic Report of Kerman City, Organization of Statistics. 1st Edn., Information and Computer Services of Kerman Municipality, Kerman, ISBN: 964-7436-76-9, pp: 418.

Power Ministry, 2005. The Reserves of Iran Water Resource. 2nd Edn., Publication of Power Ministry, Kerman, ISBN: 964-0733-38-J, pp: 347.

Power Ministry, 2007. Under Security Office about Study to the Water Basis of Kerman Plain, Water Level of Pattern Plain of Kerman Composing Office. 4th Edn., Publication of Power Ministry, Kerman ISBN: 964-6348-04-J, pp: 442.
Rahimi, H. and J. Momeni, 2004. Qanat role in sustainable development in Iran arid and semi-arid regions. Ettelaate Syasi-Eghtesadi, 9: 245-271.

Sameny, J., 1993. Title and Subject Glossary of Cities. 1st Edn., Publication of Jahane Andishe, Mashhsd, ISBN: 964-2644-72-M, pp: 243.

Schneier-Madanes, G. and C. Marie-Francoise, 2010, Water and Sustainability in Arid Regions. In: High Demand in a Land of Water Scarcity: Iran, Zehtabian, G., H. Khosravi and M. Ghodsi (Eds.). Springer, London, New York, ISBN: 13: 9789048127757, pp: 75-86.

Semsar Yazdi, A.A., A.L. Khaneiki and B.D. Manshadi, 2005. A survey on the Qanats of Bam. 1st Edn., Publication Consulting Engineers Hlyl Water, Yazd, ISBN: 964-06-77-08-6, pp: 47.

Soule, D.C., 2006, Urban Sprawl: A Comprehensive Reference Guide. 1st Edn., Greenwood, USA., ISBN: 0313320381, pp: 592.

Stiros, C., 2006. Accurate measurement with primitive instruments: The paradox in the Qanat design. J. Archaeol. Sci., 33: 1058-1064. DOI: 10.1016/j.jas.2005.11.013

Syful Islam, M., 2007. Physical density and urban sprawl: A case of Dhaka city. Master Thesis, Stockholm.

Twahir, S.F., 1976, Upgrading infrastructure in a historic town: Management of water supply systems in Lamu, Kenya. Master Thesis, Sweden.

Zangiabadi, A., 2009. Geography and Urban Planning in Kerman. 1st Edn., Publication of Kerman Center, Tehran, ISBN: 978-964-9908-63-2, pp: 264.

Zendeh Del, H., 1999. Comprehensive Guide of Iran, Isfahan Province. 1st Edn., Iran Garden Publication, Tehran, ISBN: 964-6635-60-1, pp: 222. 